\title{
Mix Design of Gepolymer Concrete for varying ratio of $\mathrm{Na}_{2} \mathrm{SiO}_{3} / \mathrm{NaOH}$
}

\author{
U.R. Kawade \\ Research Scholar,SSBT, C.O.E.T, Jalgaon \\ Dr. M. Husain \\ Prof. and Head, Civil Engineering Dept., \\ SSBT,C.O.E.T, Jalgaon
}

\begin{abstract}
Every year production of cement increases with increasing demand of construction Industries. Therefore rate of emission of carbon dioxide into the atmosphere also increases. Portland cement is one of the most energy intensive construction materials. Each ton of Portland cement releases a ton of carbon dioxide into the atmosphere. On the other side fly ash is waste material available from thermal power plant. Replacement of cement by fly ash is possible up to certain extent due to pozzolanic activity of fly ash. For complete possible of cement by fly ash, it is necessary to activate the fly ash by using alkaline activators. In present investigation sodium based activators are used. Sodium hydroxide solution having different molarity concentration is used \& Sodium silicate solution with $\mathrm{Na}_{2} \mathrm{O}=15.06 \%, \mathrm{SiO}_{2}=34.01 \%$, $\mathrm{H}_{2} \mathrm{O}=50.93 \%$ were maintained constant throughout the experimentation. Geopolymer technology is new technology in which pozzolanic material which is rich in silica and alumina is used and it is activated by alkaline activators. Alkaline solutions may be sodium based or potassium based. Generally sodium based solution is used from economy and availability point of view.
\end{abstract}

Keywords : Fly Ash, Geopolymer, Ratio of $\mathrm{Na}_{2} \mathrm{SiO}_{3} / \mathrm{NaOH}, \mathrm{Na}_{2} \mathrm{O}, \mathrm{SiO}_{2}$,

\section{INTRODUCTION}

The greatest difficulties concern the developing countries which are in urgent need of implementations. A framework capable of providing necessary building houses, goods, \& entire fundamental needs of their population. Potential for concrete $\&$ need for cement manufacture in developing countries are tremendous .Concrete is the most commonly used construction material in the world. Due to exponential use of concrete, cement production has increased at much higher speed. It is estimated that one MT of cement production approximately results into the production of one MT of carbon dioxide gas. This is the main cause of global warming. Thus the researchers are searching for alternative to cement. Davidovits $(1988 ; 1994)$ Proposed that an alkaline liquid could be used to react with the silicon ( $\mathrm{Si}$ ) and the aluminum (Al) in a source material of geological origin or in by-product materials such as fly ash and rice husk ash to produce binders (1). Because the chemical reaction that takes place in this case is a polymerization process, he coined the term 'Geopolymer' to represent these binders. The main constituents of geopolymer concretre are source material which is rich in silica \& alumina, alkaline liquids .The alkaline liquids are prepared from soluble alkali metals which are nmainly sodum or potassium based. Sodium based solutions are easily available $\&$ are economical as compared to potassium based solutions

In geopolymer technology $100 \%$ replacement of cement is possible by using the source materials and alkaline liquids. The most commonly used source materials are fly ash, GGBS, Metakeolin. In India more than 100 million tons of fly ash is produced annually, out of which $17-20 \%$ fly ash is utilized either in concrete as a part replacement of cement or workability improving admixture or in stabilization of soil [6-7].

Molarity of $\mathrm{NaoH}$ is also important to enhance the properties of Geopolymer concrete. Generally sodium hydroxide is available in solid state in the form of flakes or pellets. Cost of sodium hydroxide depends upon purity of substance. Sodium silicate is a combination of $\mathrm{Na}_{2} \mathrm{O}$ and $\mathrm{SiO}_{2}$. Ratio of $\mathrm{Na}_{2} \mathrm{O} / \mathrm{SiO}_{2}$ also plays important role in Geopolymer concrete. This study aims to synthesize geopolymer concrete for varying ratio of $\mathrm{Na}_{2} \mathrm{SiO}_{3} / \mathrm{NaOH}$.

\section{PREVIOUS RESEARCH}


R. Anuradha et.al. ( 2011), studied on modified guidelines for geopolyme concrete mix design using Indian Standard. According to them presence of sodium silicate as a gel form takes delay in setting at ambient temperature . It is recommended by Anuradha that heat curing is necessary. S.V. Patankar et.al. (2013) carried the research on effect on water to geopolymer binder ratio on the production of flyash based geopolemer concrete. According to them water to geopolymer binder ratio should be in the range of 0.25 to 0.35.S.V.Patankar et. al. (2013) studied on fineness of fly ash on properties of geopolymer concrete. He concluded that mass density of geopolymer concrete increases with increase in fineness of fly ash.

\section{EXPERIMENTAL PROGRAM}

Fly ash used in this research is obtained from Dirk India Ltd., Nashik and is low calcium class F fly ash named as POZZOCRETE 63. Table 1 shows test results for pozzocrete 63 obtained from Dirk India. NaoH flakes were procured from Abhay Chemicals, Ahmednagar.Na2Sio3 solution was procured from Shanti Chemicals, Belgum. Locally available river sand was used. Sand was used having fineness modulus of 3.15. Coarse aggregates of size $20 \mathrm{~mm} \& 12.5 \mathrm{~mm}$ obtained from crushed basalt stones were used. $\mathrm{NaoH}$ solution was prepared one day before use. In present investigation water to geopolymer binder ratio was kept as 0.35 . But, ratio of sodium hydroxide to sodium was changed. Mix design was carried out as per guidelines given in research work carried by Dr. S.V.Patankar .Table 2 shows material required for $\mathrm{P} 63$ fly ash for varying ratio of $\mathrm{Na}_{2} \mathrm{SiO}_{3} / \mathrm{NaOH}$. Mix design procedure suggested by Dr. S.V.Patankar(2) is used to obtain the quantities of materials.

Table 1. POZZOCRETE 63 TEST CERTIFICATE (SPECIMEN) AS PER DIRK INDIA PVT.LTD.

\begin{tabular}{|c|c|c|c|c|}
\hline Test No. & Test & Unit & $\begin{array}{c}\text { IS-3812 } \\
\text { Specification }\end{array}$ & $\begin{array}{l}\text { Typical Test } \\
\text { Results }\end{array}$ \\
\hline 1 & $\begin{array}{l}\text { Fineness Specific Surface by } \\
\text { Blaines Permeability Method } \\
\text { (Min.) }\end{array}$ & $\mathrm{m}^{2} / \mathrm{kg}$ & 320 & 435 \\
\hline 2 & $\begin{array}{c}\text { ROS (Residue Over Sieve) \# } \\
350 \text { (45 Microns) Max. }\end{array}$ & $\%$ & 34 & 9.88 \\
\hline 3 & Lime Reactivity (Min.) & $\mathrm{N} / \mathrm{mm}^{2}$ & 4.5 & 7.40 \\
\hline 4 & Moisture Content (Max.) & $\%$ & 2 & 0.28 \\
\hline 5 & Autoclave Expansion (Max.) & $\%$ & 0.8 & 0.023 \\
\hline \multirow[t]{9}{*}{6} & Chemical Analysis & & & \\
\hline & Test & $\%$ & IS Specification & \\
\hline & Loss On Ignition (Max.) & $\%$ & 5 & 1.00 \\
\hline & $\mathrm{SiO}_{2}+\mathrm{Al}_{2} \mathrm{O}_{3}+\mathrm{Fe}_{2} \mathrm{O}_{3}$ & $\%$ & 70 min. by mass & 93.15 \\
\hline & $\mathrm{SiO}_{2}$ & $\%$ & 35 min. by mass & 60.42 \\
\hline & $\mathrm{MgO}$ & $\%$ & 5 max. by mass & 1.82 \\
\hline & $\mathrm{SO}_{3}$ & $\%$ & 3 max. by mass & 0.83 \\
\hline & $\mathrm{Na}_{2} \mathrm{O}$ & $\%$ & 1.5 max. by mass & 0.47 \\
\hline & Total Chlorides & $\%$ & 0.05 max. by mass & 0.031 \\
\hline
\end{tabular}


TABLE 2 : MATERIAL REQUIRED FOR DIFFERENT NA $2 \mathrm{SIO}_{3} / \mathrm{NAOH}$ RATIO AND P 63

\begin{tabular}{|c|c|c|c|c|c|c|}
\hline Sr. No. & Molarity & $\mathrm{Na}_{2} \mathrm{SiO}_{3} / \mathrm{NaOH}$ & $\begin{array}{l}\text { Fly Ash } \\
\left(\mathrm{kg} / \mathrm{m}^{3}\right)\end{array}$ & $\begin{array}{l}\text { Fine } \\
\text { Aggregate } \\
\left(\mathrm{kg} / \mathrm{m}^{3}\right)\end{array}$ & $\begin{array}{l}\text { Coarse } \\
\text { Aggregate } \\
\left(\mathrm{kg} / \mathrm{m}^{3}\right)\end{array}$ & $\begin{array}{l}\text { Extra Water } \\
\left(\mathrm{kg} / \mathrm{m}^{3}\right)\end{array}$ \\
\hline 01 & \multirow{3}{*}{8} & 1.0 & \multirow{3}{*}{410} & 676.98 & 1285.28 & 19.237 \\
\hline 02 & & 1.5 & & 675.88 & 1283.21 & 22.41 \\
\hline 03 & & 2.0 & & 675.03 & 1281.89 & 24.57 \\
\hline 04 & \multirow{3}{*}{10} & 1.0 & \multirow{3}{*}{410} & 675.86 & 1283.16 & 22.42 \\
\hline 05 & & 1.5 & & 674.97 & 1281.48 & 25.04 \\
\hline 06 & & 2.0 & & 674.39 & 1280.36 & 26.74 \\
\hline 07 & \multirow{3}{*}{12} & 1.0 & \multirow{3}{*}{410} & 675 & 1281.17 & 25.53 \\
\hline 08 & & 1.5 & & 674.137 & 1279.88 & 27.477 \\
\hline 09 & & 2.0 & & 673.69 & 1279.03 & 28.769 \\
\hline 10 & \multirow{3}{*}{13} & 1.0 & \multirow{3}{*}{410} & 674.168 & 1279.95 & 27.387 \\
\hline 11 & & 1.5 & & 673.62 & 1278.91 & 28.96 \\
\hline 12 & & 2.0 & & 673.26 & 1278.24 & 30.01 \\
\hline 13 & \multirow{3}{*}{14} & 1.0 & \multirow{3}{*}{410} & 673.53 & 1278.74 & 29.23 \\
\hline 14 & & 1.5 & & 673.12 & 1277.95 & 30.44 \\
\hline 15 & & 2.0 & & 672.84 & 1277.42 & 31.24 \\
\hline
\end{tabular}

\section{CONCLUSION}

Fineness of fly ash is very important to decide quantity of fly ash. As fineness of fly ash goes on increasing, less quantity of fly ash is required. It is observed that fine aggregate quantity is slightly decreased as we increase the ratio of $\mathrm{Na}_{2} \mathrm{SiO}_{3} / \mathrm{NaOH}$.Also, quantity of coarse aggregate goes on decreasing as there is increase in ratio of $\mathrm{Na}_{2} \mathrm{SiO}_{3} / \mathrm{NaOH}$. But extra water required increases as there is increase ratio of $\mathrm{Na}_{2} \mathrm{SiO}_{3} / \mathrm{NaOH}$. Fly ash quantity depends on fineness of fly ash. $\mathrm{Na}_{2} \mathrm{SiO}_{3}$ is sticky gel and it requires more time for setting in winter and rainy season as we increase ratio of $\mathrm{Na}_{2} \mathrm{SiO}_{3} / \mathrm{NaOH}$. While Preparing $\mathrm{NaOH}$ solution, care should be taken to avoid irritation to skin and eyes . Also. $\mathrm{NaOH}$ should prepare one day before use of it in concrete.

\section{REFERENCES}

[1] Davidovits J (1995) Global warming impact on the cement and aggregate industries. World Res Rev 6(2):263-278

[2] Patankar SV, Ghugal YM , Jamkar SS (2015), Mix Design Procedure of fly ash based geopolymer concrete, Springer India 2015

[3] Patankar SV, Jamkar SS, Ghugal YM (2012) Effect of sodium hydroxide on flow and strength of fly ash based geopolymer mortar. J Struct Eng 39(1):7-12

[4] Jamkar SS, Ghugal YM, Patankar SV (2013) Effect of fineness of fly ash on flow and compressive strength of geopolymer concrete. Indian Concr J 87(4):57-61

[5] Patankar SV, Jamkar SS, Ghugal YM (2014) Effect of grading of fine aggregate on Flow and compressive strength of geopolymer concrete. In: UKEIRI concrete congress-innovations in concrete, pp 1163-1172

[6] Patankar SV, Jamkar SS, Ghugal YM (2013) Effect of water-to-geopolymer binder ratio on the production of fly ash based geopolymer concrete. Int J Adv Technol Civ Eng 2(1):79-83 